\title{
Kent Mobilyaları Tasarım Dersi Stüdyo Çalışması; Üst Örtü-Oturma Birimi ve Piknik Donatısı Tasarımı
}

\author{
Hilal KAHVECI ${ }^{1}{ }^{*}$, Parisa GÖKER ${ }^{2}$ \\ 1,2 Bilecik Şeyh Edebali Üniversitesi, Güzel Sanatlar ve Tasarım Fakültesi, İç Mimarlık ve Çevre Tasarımı \\ Bölümü,11230, BİLECİK
}

\section{Öz}

Dünya çapında yaşanan hızlı kentleşme olgusu kentsel alanlardaki birimlerin işlevselliğini arttırma, sürdürülebilir tasarım ve estetik olarak nitelik sağlama açısından kent mobilyaları kavramı önem kazanmıştır. Kent mobilyaları kamusal mekanın temel gereksinimlerini karşılamakla beraber, kent yaşamını daha zevkli ve anlamlı kılan, konfor ve estetik sunan elemanlar olarak, toplumsal yaşama olumlu katkılar sağlamaktadırlar. Bu nedenle kentsel ortamlarda yaşayan insanların sosyo-kültürel farklılıkları göz önüne alınarak, mobilyanın yeri, biçimi, işlevi vb. özellikleriyle kent kimliğini destekleyecek özgün ve yaratıcı biçimde tasarlanmalıdır. Bu çalışmada Bilecik Şeyh Edebali Üniversitesi, Güzel Sanatlar ve Tasarım Fakültesi, Endüstri Ürünleri Tasarımı Bölümündeki öğrencilerin bir stüdyo çalışması ele alınmıştır. Kent Mobilyaları Tasarımı dersi kapsamında 2 öğrencinin farklı türdeki kentsel mobilya tasarımları (üst örtü ve oturma birimi, barbekü ve piknik masası), problemin belirlenmesinden sonuç ürününe kadar değerlendirilmiş, mobilyaların görsel ve işlevsel özellikleri ortaya koyulmuştur. Tasarlanan kentsel mobilyalar öğrencilerimizin son dönem stüdyo çalışmasında, 3,5 yıllık bilgi birikimiyle tasarladıkları ürün olması açısından önemlidir. Sonuç olarak öğrencilerin tasarladıkları ürünlerin kullanıcı istek ve ihtiyaçları doğrultusunda, sürdürülebilir yaklaşımla ele alındığı nitelikli tasarımlar elde edilmiştir.

Anahtar Kelimeler: Kent mobilyaları, tasarım eğitimi, ergonomik tasarım

\section{Studio Studies within the Scope of Urban Furniture Design; Cover, Seating Unit and Picnic Table Design}

\begin{abstract}
The phenomenon of rapid urbanization, which is experienced worldwide, has gained importance in the concept of urban furniture in terms of increasing the functionality of units in urban areas, providing sustainable design and aesthetic quality. Urban furniture is described as the basic requirement of public spaces. Urban furniture makes positive contributions to social life as elements that offer comfort and aesthetics to life. For this reason, considering the socio-cultural differences of people living in urban environments, it should be designed in a unique and creative way to support the urban identity with its features such as location, form, function of the furniture. In this research, a studio study of students in Bilecik Seyh Edebali University, Faculty of Fine Arts and Design, Department of Industrial Design is discussed. Different types of urban furniture designs (cover and seating unit, and picnic table) of 2 students were evaluated from the determination of the problem to the final product, and the visual and functional features of the furniture were revealed. Urban furniture evaluated within the scope of the research is important in terms of being a product designed with 3.5 years of knowledge of students in the recent studio work. In the conclusion section, qualified designs are obtained, which are handled with a sustainable approach in line with user requests and needs.
\end{abstract}

Keywords: Urban furniture, sustainable design, ergonomic design.

\footnotetext{
*Sorumlu Yazar (Corresponding Author): 


\section{Giriş}

Kentleşme, gittikçe yoğunlaşan ve zorlaşan yaşam şartları toplumsal faaliyetleri oldukça arttırmıştır. Günümüzde kentlerin ve kentsel mekânların kalitesini iyileştirme çalışmaları giderek artan bir önem kazanmaktadır (İnceoğlu ve Aytuğ 2019). Kentler yalnız yapılarla değil yapıların dışında kalan alanlarla da ele alınır. Kentsel mekanları tanımladığımızda, değişen sosyo- ekonomik koşullara ve kentlerin kültürel dokusuna cevap verebilen "yaşayan organizmalar" olarak ifade edilmektedir. Kentsel mekânın yaşanılabilirliği ise tasarımının kullanıcılarının beklentilerine cevap verebilme yeteneği ile belirlenir (Çoban ve Demir 2014).

Kent mobilyaları kentsel açık alan kullanıcılarının, bu alanlarda vakit geçirme süresini ve yaşam kalitesini arttırmada çok önemli bir unsurdur (Çoban ve Demir 2014). Kentsel alanlarda kullanıcılara daha konforlu ve rahat bir yaşam alanı sunmak ülkemizde henüz yeterli seviyede olmayan kentsel mobilya endüstrisinin gelişimine katkıda bulunması açısından önem taşımaktadır. Bulut vd. (2008) donatı elemanlarını, insanın kent dokusu içindeki bireysel ve toplumsal yaşamını kolaylaştıran, kullanıcılar arası iletişimi sağlayan, mekâna işlevsel ve estetik yönden belirli bir anlam kazandıran, değişik nitelik ve niceliklerde olan, mekânı tanımlayan ve tamamlayan nitelikler, objeler olarak tanımlar. Mekanın bir parçası olarak tasarlanan donatılar bir sistem oluşturmalıdır. Mekan-etkinlik-donatı arasında bir uyum olmalı, hepsi bir arada hareket etmelidir. Kullanıcı ihtiyaçlarına cevap vermesi gereken donatılar, uygun ölçülerde ve özelliklerde olmalıdır (Aksu 2012; Düzenli vd. 2018). Bu nedenle kent peyzajını dinamik hale getiren canlandırıcı etkileri açısından da büyük önem taşıyan donatı elemanları işlevsel olarak da büyük önem taşımaktadır.

Kentsel açık - yeşil alanlar insanların kamusal alanlarda daha fazla zaman geçirmesini sağlamaktadır (Zavari vd. 2016). Kent mobilyaları sokaklarda doğrudan veya dolaylı olarak sokakların kullanımı ile ilgili birçok işleve hizmet eden ve sokakların kentsel alan olarak daha iyi kullanılmasına yol açan ögeler olarak tanımlanmaktadır. Sokaklar ve caddelerin görevi sadece hareket geçişlerini sağlamak değildir, aynı zamanda insanların yaşamı ve faaliyetlerini içeren geliştiren yaşam alanlarıdır (Radwan ve Morsy 2014). Kent mobilyaları kent ve çevresini süslemek amacı ile kullanılan dekoratif unsurlar topluluğu değildir. Bu ögelerin görevi işlevselliğini sağlamak ve nüfus ihtiyaçlarını karşılamak, yaşamlarını kolaylaştırmak ve konforlarına katkıda bulunmak için bir takım fonksiyonel gereksinimleri yerine getirmelidir (Gamito ve Sousa 2018). Kent mobilyaları çocuklar ve yaşlıları gibi farklı kullanıcıların ihtiyacını ele alarak sosyalleşmeyi teşvik etme ve insanların birbiri ile iletişim kurmasını güçlendirme amacını barındırmalıdır (Gupta ve Bhatti 2015). Kent mobilyalarının tasarımında ve üretiminde oldukça değişik etmenler yer almaktadır. Bu etmenler arasında, örf adetler, önyargılar, tarihsel doku, alışkanlıklar, ihtiyaçlar gibi faktörlerin var ettiği toplumsal yön, algılama sonucunda oluşan psikolojik yön, kullanılan malzeme özelliklerinin kazandırdığı anlamsal yön ve tasarım boyutunun getirdiği estetik yön gibi değişik faktörler söz konusudur (Akyol 2006). Tasarım karmaşık, çoğu zaman çelişkili, doğrusal olmayan bir süreçtir. Tasarım farklı yaklaşım ve etkileşimlerle bir denemeyanılma sürecini takip eder, hele ki tasarlayan, kavram üretimi ve tasarım dünyasına yeni giren öğrencilerse (Bielefeld ve Khouli 2007). Tasarım eğitimi uzun ve zor bir süreçtir. Bu süreçte yaratıcılığın öğrencilere kazandırılması gereklidir. Ayrıca öğrencilerinin bilişsel yetenekleri geliştirilmeli ve öğrenme olanakları arttırılmalıdır (Güneroğlu ve Bekar 2020). Güncel hayattaki görsel algı, işitme, koku, tat ve dokunma gibi duyuları da içine alan mekan ve zaman kavramlarıyla boyut kazanan bir eğitim sürecidir (Acar ve Bekar 2017).

Tasarım bir nesnenin biçimini ve işlevini yaratmadır. Tasarım ürünleri, makineleri ve strüktürleri amaçlarına uygun olarak biçimlendirmeyi kapsadığı gibi, estetik olarak göze de hoş görünmesi gerekmektedir (Bayazıt 2012). Bu nedenle tasarım eğitiminde öğrenmeyi gerçekleştirebilmek son derece önemli ve gereklidir. Öğrenme, karşılıklı etkileşim içinde gerçekleşen bir süreçtir ve başarılı bir öğrenme süreci geçiren öğrenciler özgün ve nitelikli ürünler ortaya koyan başarılı tasarımlar gerçekleştirebilir. Böylece tasarım eğitiminde öğrenme aşamasındaki, öğrenmeyi etkileyen ve anlaşılabilir kılan yöntem ve teknikler önem kazanmaktadır. Gerek manuel gerekse bilgisayar ortamında hazırlanmış iki ve üç boyutlu çizim anlatımları, görseller, bilgisayar ortamında hazırlanmış animasyonlar, maket anlatımları bu teknikler arasında sayılabilir. Tasarımların iki ve üç boyutlu çizim teknikleri ile anlatımları tasarım eğitiminin ortak dilidir. Bu çizim tekniklerinin kullanımı tasarlama sürecinin her aşamasında etkin bir çözümleme aracıdır (Acar ve Bekar 2017).

Ergonomi ve tasarım kavramları iki ayrı anlamı içeren kavramlar olmalarına karşın, bir bütünün iki parçası gibi birbirlerini tamamlamaktadırlar. Ergonomiyi; ürün tasarımında insan odaklılığı esas alan bir kavram olarak görmek ve insan için tasarım olarak adlandırmak mümkündür. Tasarım ve ergonomi kavramlarının esas odak noktasını insan oluşturmaktadır. Antropometrik, yunanca da Antrops (insan) ve metikos (ölçü) sözcüklerinden oluşan, insan vücudunun ölçülerini konu edinen bir bilim dalıdır. Antropometri; yalnızca vücudun bölüm ve öğelerinin ölçüleri ile ilgilenmez. Aynı zamanda belli bir ölçünün değişkenliğini ya da yaş veya tür gruplarının bu ölçüden ne oranda uzaklaştıklarını da inceler. İnsanın antropometrik boyutları statik ve dinamik boyutlar olmak üzere ikiye ayrılır (MEB 2014). 
- Statik antropometrik boyutları: Statik antropometrik boyutlar; insan vücudunun "standart" duruşta hareketsiz olarak bulunurken alınan ölçülerdir. Örneğin; ayakta boy, göz, dirsek, diz yüksekliği, omuz genişliği, boyutları ile oturan insanın boy, göz, dirsek ve diz yüksekliklerini içerir.

- Dinamik antropometrik boyutlar: Dinamik antropometrik boyutlar, insan vücudunun belli bir eylem içinde hareket halinde iken alınan vücut ölçüleridir.
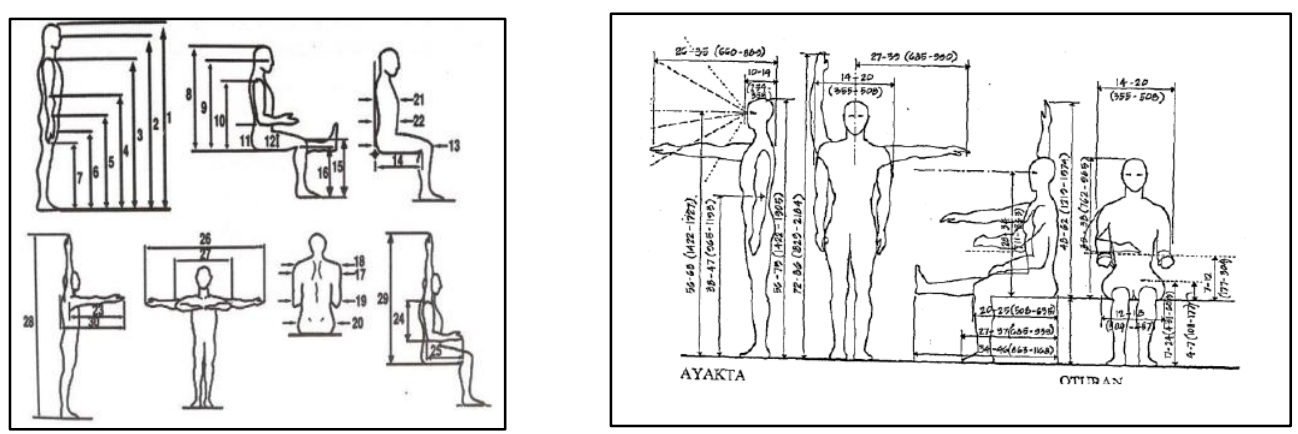

Şekil 1. Antropometrik Ölçüler (Kaya ve Özok 2017; İçemer 2015)

Teknolojinin sürekli ilerlemesi ve yaşam koşullarını kolaylaştırması, dijital yaşamın her alanında kullanılmasının gerekliliğini ortaya çıkarmış ve bilgisayarları da mimari eğitimde kullanmayı mecburi hale getirmiştir. Bilgisayar destekli tasarım programlarıyla yapılan çalışmalar tasarımcıya çizme ve karar verme aşamalarında yardımcı olmalarının yanı sıra, program özellikleri sayesinde projelerin de görsel açıdan daha etkili, estetik, renkli ve daha gerçekçi sunulmasını sağlarlar. Bu çalışmanın amacı kentsel mobilya tasarımı dersi stüdyo çalışması süresi içinde tasarım aşamalarının ele alınması ve kentsel mekanlarda ki kent mobilyası ihtiyacının karşılanması için tasarım disiplini çerçevesinde seçenekler sunmaktır. Bu doğrultuda öğrenciler tarafından tasarlanan üst örtü ve oturma birimi ve piknik donatı birimleri tasarım aşamalarıyla birlikte ele alınmıştır.

\section{Materyal ve Metot}

\subsection{Materyal}

Çalışmanın materyali öğrenciler tarafından 2018-2019 Bahar Yarıyılı eğitim- öğretim döneminde Kent Mobilyaları Tasarımı dersi kapsamında tasarlanan çalışmalar arasından seçilmiştir. TAS408 Mesleki Yeterlilik Uygulamaları (Kent Mobilyaları Tasarımı II) dersi için dönem sonunda 3 proje teslim edilmiş tasarım sürecini ve ürün geliştirmeyi ifade eden 2 çalışma incelenmiştir. Yardımcı materyal olarak; konuyla ilgili literatür çalışmaları, potansiyel kullanıcılarla yapılmış görüşmeler (anketler), üretici firmalarla yapılmış görüş̧melerden yararlanılmıştır.

\subsection{Metot}

Bu çalışma BŞEÜ Endüstri Ürünleri Tasarımı Bölümünde 2018-2019 bahar yarıyılı son dönem projesi olan Kent Mobilyaları Tasarımı dersi kapsamında yürütülen çalışmanın ürünle sonuçlanan aşamalarını içermektedir. Bu ders sadece yüz yüze eğitim şeklinde yürütülmektedir. Doğru yöntem seçiminde kişinin çalışma tarzına, becerilerine ve çözümü gereken tasarım problemine bağlıdır. Genel olarak ürün tasarımın oluşmasında 1.Problem, 2. Bilgi toplama, 3.Çözümleme, 4.Seçenekler, 5. Değerlendirme ve son aşama 6. Geliştirme aşamaları takip edilmektedir. Bayazıt (2004) ise çalışmasında ürün tasarlama sürecini analiz, sentez ve değerlendirme olarak 3 aşamada ele almıştır. Tasarım eğitimi ve kentsel mobilya tasarım sürecini ele alan benzer çalışmalardan faydalanılarak (Akyol 2006; Acar ve Bekar 2017) oluşturulan tasarım süreci Şekil 2'de detaylıca verilmiştir. 


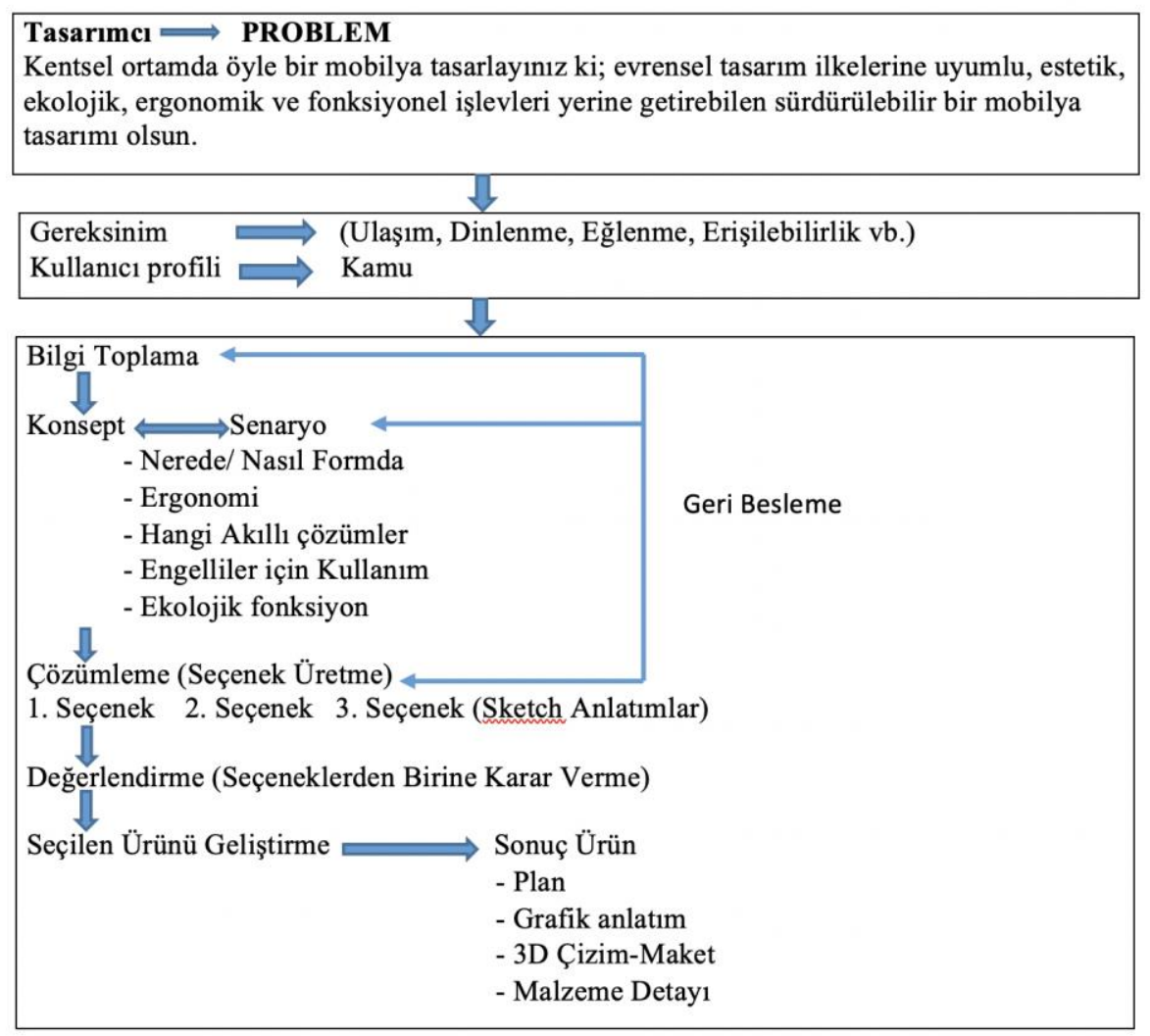

Şekil 2. Mesleki Uygulama Dersinde izlenen tasarım süreci

\section{Bulgular ve Tartışma}

\section{1. Üst Örtü ve Oturma Birimi Tasarımı}

Ülkemizde olduğu gibi güneşli ya da sürekli yağış alan ülkelerde tüm dış mekân tasarımında en çok kullanılan örtü elemanları gölge sağlama işlevi yanında oturma, dinlenme, dış koşullardan korunma (yağmur, rüzgâr, toz vb.) mekân oluşturma ve ilgi ya da odak noktası olma işlevini de üstlenirler. Örtü elemanları tek ya da modüler olarak, konsol, yapı saçağı, çadır ya da asma konstrüksiyon şeklinde çeşitli malzemeler kullanılarak tasarlanabilirler. Sistemleri; asma tipler dışında taşıyıcı ayak, yatay taşıyıcı, örtü veya çıtalardan oluşur. Asma ya da germeli sistemlerde ise halat, çelik halat, yatay taşıyıcılar ve örtüleme malzemeleri kullanılır. Ahşap, alüminyum, çelik ve beton malzemeler dayanıklılıkları dolayısıyla tercih edilmektedirler (URL 1). Oturma elemanları, dinlenme, sohbet etme, birini bekleme veya sadece zaman geçirme gibi bir eylem ihtiyacını karşılamak için kullanılırlar (Düzenli vd. 2018). Malzemeler dış mekânda kalıcı ve dayanıklı olabilecek türden olmalıdır. Bu nedenle metal alaşımları, ahşap, beton, plastik en çok tercih edilen malzemelerdir. Örtü birimi ve oturma birimi tasarımı eğitimi için bu aşama da konuya ilişkin literatür taraması yapılmıştır. $\mathrm{Bu}$ aşamanın devamında öğretim üyesi denetiminde öğrenciler tarafından konuyla ilgili beyin firtınası gerçekleştirilmiştir. Artık öğrenciler somut olarak tasarım çalışmasına hazır duruma getirilmiş anket ve kalite evi çalışmalarına geçilmiştir.

\subsubsection{Kullanıcı İhtiyaçlarının Tanımlanması}

İnsan doğası gereği ve ihtiyaçlarından dolayı sürekli bir beklenti içerisindedir. Kullanıcılar bu beklentilerini karşılayan ürünleri, hizmetleri ve mekânları tercih etmektedirler. Bu nedenle araştırmalarımız sonucu geliştirdiğimiz kent mobilyası, kullanıcıların beklentisine tam anlamıyla karşılık verecek şekilde tasarlanmıştır. Tasarladığımız kent mobilyası kaliteli bir malzeme yapısı, ergonomik olması ve fonksiyonelliği ile hizmetinize sunulacaktır. Tasarlanacak kentsel mobilyalar 68 bin nüfusa sahip Bilecik kentinde kullanılacaktır. Bu nedenle farklı hedef kitle büyüklükleri ve hata düzeyleri için gerek duyulan örneklem büyüklükleri (Baş 2003; Yazıcıoğlu, Erdoğan 2004) tablosuna göre $\pm \% 10$ örnekleme hatası (d) ile örneklem sayısı 61 olarak gözükmektedir. Kullanıcı ihtiyaçlarının tanımlanması aşamasında rastgele belirlenen 80 kişi ile yüz yüze görüşme tekniği ile anket çalışması gerçekleştirmiştir. Anket çalışmasında sorulan sorular ve cevap yüzdeleri Tablo 1'de verilmiştir. 
Tablo 1. Anket soruları ve sonuçları

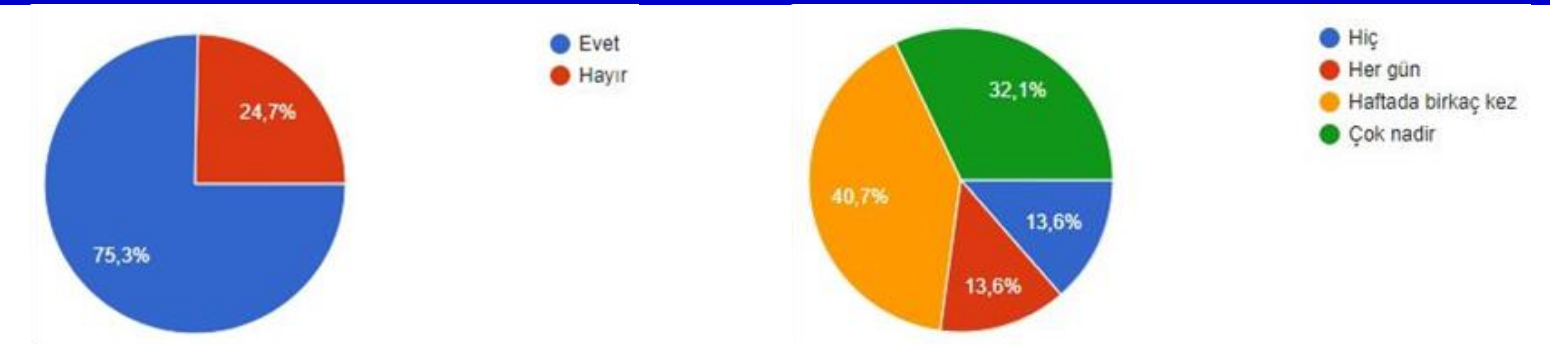

Kentsel mekânlarda üst örtü donatısına ihtiyaç Ne sıklıkla örtü ve oturma birimi kullanıyorsunuz? duyuyor musunuz?

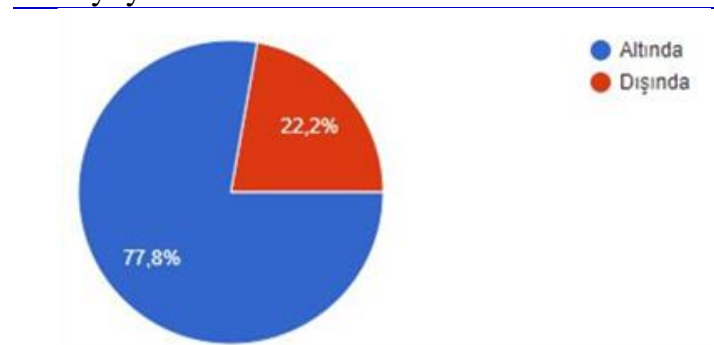

Örtü biriminin altında mı oturmayı tercih edersiniz (güneş, yağmur vb. korunma amaçli), dışında mı?

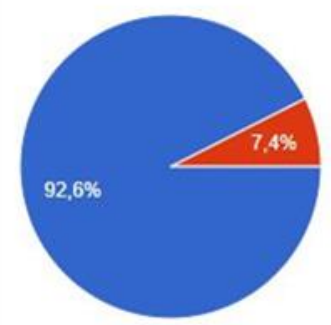

Sizce örtü donatısı estetik mi olmalıdır?

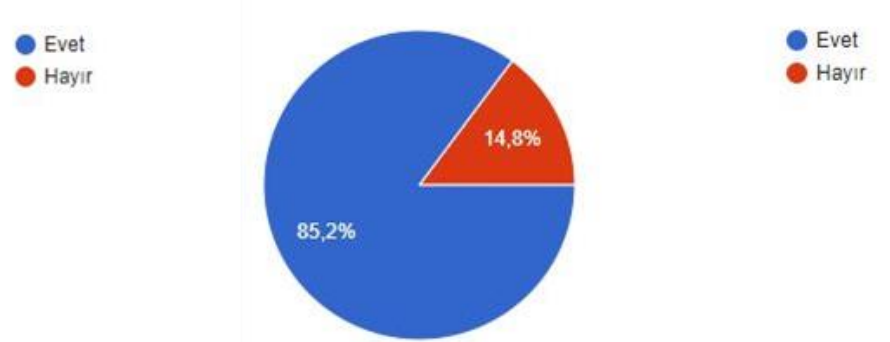

Sizce örtü elemanında yeşil doku bulunmalı mı?

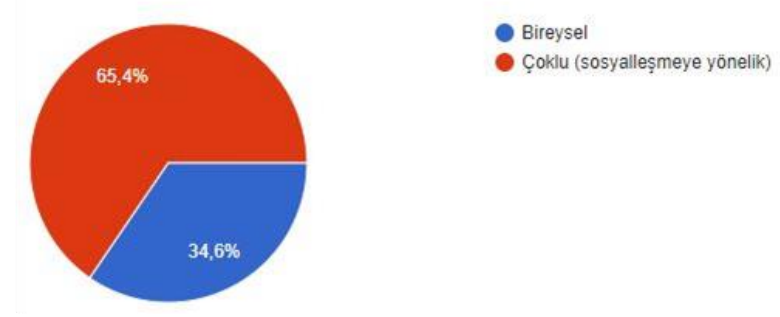

Oturma biriminin nasıl olmasinı istersiniz?

\subsubsection{Kalite Evi}

Kalite evinin esası müşteri talebi istek ve beklentilerini karşılayan ürünlerin tasarımlanması düşüncesi olduğundan kalite evinin temelinde de müşterilerin beğeni ve seçimlerini yansıtarak tasarlanması gerekliliği vardır (Güllü, Ulcay 2002). Bu çalışmada kalite evinde kullanıcılarla yapılan anketler, yüz yüze görüşmeler ve piyasa araştırması sonucunda tanımlanmış olan müşteri ihtiyaçlarının neler olduğu ve bunlara karşılık gelen hizmetimizin karşılaştırması yapılmıştır. Bu aşamada ihtiyaçlara karşılık, hizmetler arasındaki güçlü, orta ve zayıf bağlar tanımlanmıştır. Tablo 2'de müşteri ihtiyaçlarının, üst örtü ve oturma elemanının verdiği hizmete karşılık gelen bağı daha net bir şekilde görülecektir. 


\begin{tabular}{|c|c|c|c|c|c|c|c|c|c|c|c|c|c|c|}
\hline \multicolumn{15}{|c|}{ İHTIYAÇLAR } \\
\hline \multirow{5}{*}{ 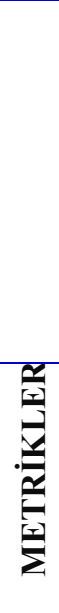 } & $\begin{array}{c}\text { İhtiyaçlar ve } \\
\text { Metrik } \\
\text { İlişkiler }\end{array}$ & 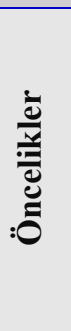 & 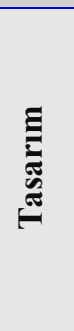 & 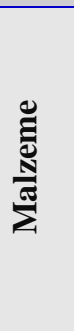 & 羡 & 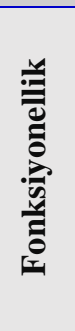 & 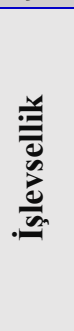 & 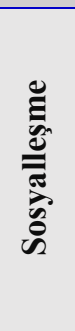 & 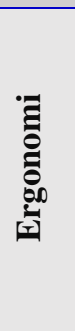 & 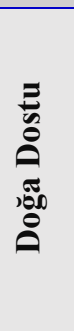 & 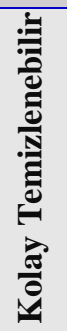 & 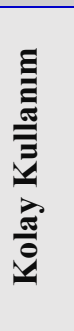 & 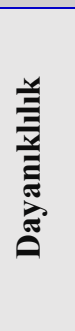 & 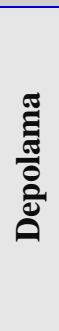 \\
\hline & Tercih & 2 & 0 & 0 & 0 & 0 & 0 & 0 & 0 & 0 & - & 0 & $\triangle$ & - \\
\hline & $\begin{array}{c}\text { Kullanım } \\
\text { Amacı }\end{array}$ & 4 & ○ & ○ & $\triangle$ & $\mathbf{O}$ & 0 & ○ & ○ & ○ & - & ○ & $\triangle$ & - \\
\hline & Sorunlar & 5 & ○ & ○ & $\triangle$ & ○ & ○ & ○ & ○ & O & - & O & ○ & - \\
\hline & Yenilik & 3 & ○ & ○ & ○ & $\mathbf{O}$ & $\triangle$ & ○ & ○ & ○ & - & - & - & - \\
\hline & ○ Güçli & & $\mathrm{OO}$ & șik & $\triangle$ & f İl & & Yc & & & & & & \\
\hline
\end{tabular}

Kalite evi çalışmasının sonuçlarını değerlendirdiğimizde;

1. Kullanıcıların bir kent mobilyasından beklentisi diğer tüm beklentilerin yanında fonksiyonelliktir. Uzun veya kısa süreli de olsa vakit geçirecekleri mekânda wi-fi, şarj etme cihazı, bisiklet park yerleri gibi fonksiyonlara ihtiyaç duymaktadırlar. Tasarlanan oturma birimlerinde şarj etme yerleri, mekânda wi-fi, örtü biriminde yeşil doku olması ile kullanıcıların beklentisine karşılık vermektedir. Bu bağlamda yapılan çalışmalar kent mobilyası tasarımının ilk özelliklerini kapsıyor.

2. Bahsedildiği üzere sosyalleşmenin asıl önemli konu ve ihtiyaç olduğu düşünülürse tasarlanan kent mobilyasının özellikle bu ihtiyacı karşılaması beklenmektedir. Bu bağlamda kullanıcıları sosyalleşmeye teşvik edecek mekân algisı oluşturulmuştur.

3. Sürekli olarak gelişen ve betonlaşmakta olan kentlerde yeşil dokuyu görmek pek mümkün olmamaktadır. Kullanıcıların insan doğası ile bir arada yaşamak ve daha kaliteli zaman geçirmeleri için yeşil dokuya ihtiyaçları vardır. Bu sebeple örtü birimi tasalanırken yeşil doku kullanılmıştır. Aynı zamanda tasarlanan yeşil doku insanların sohbet edip, uzanabileceği, kitap okuyup müzik dinleyebileceği kaliteli vakit geçirecekleri bir alan olmuştur.

\subsubsection{Konsept Oluşturma (Senaryo)}

Konsept oluşturma aşamasında öğrencilerin yapması gereken, belirlenen konu başlığına göre tasarım stratejilerini ortaya koymalarıdır. Çalışmamızda ele alınan kent mobilyaları tasarımı kapsamında oluşturulan tasarım stratejileri aşağıdaki gibidir;

- Ana işlev; Dış etkenlerden korunma, kendini güvende hissetme ve oturma

- Diğer fonksiyonlar; ergonomi, kentsel mekânlarda daha verimli vakit geçirmek, doğa ile temas etmek, kentleşmeden uzaklaşmak.

- Kentsel mobilyanın özellikleri; Form ile çözülmüş ve yeşil örtü ile tamamlanmış oturma birimleri, tasarım kriterleri ele alınarak tasarlanmış örtü donatısı, sosyalleşerek veya bireysel olarak vakit geçirmeye yönelik tasarlanmış hareketli ve sabit oturma birimleri,

- Bisiklet park yerleri ile bisikletli kullanıcıların da mekândan yararlanabilmesi,

- Güneş panellerinden elde edilen enerji ile şarj özelliğinin kullanılabilmesi,

- Üst örtü biriminin üzerinde toplanan yağmur suyunun yer altındaki depoya ulaşabilmesi için tasarlanan kanallar.

\section{Ergonomi}

Üst örtü öğelerinin, gölge sağlama, yağmurdan koruma, dinlenme, pasif rekreasyon ve mekana üçüncü boyut sağlama gibi fonksiyonları vardır (Yücel, 2006). Kamusal alanlarda, özellikle meydan gibi büyük açıklıkların olduğu alanlarda, gölgelik elemanlar termal konforu sağlamada önemlidir. Oturma birimleriyle bütün olarak düşünülmesi gereken üst örtüler, hava akışını engellemeyen ve çevreyle uyumlu doğal malzemelerden seçilmelidir. Örtü 
birimlerinin yerden yükseklikleri 2,5-3m olup gölgeleyici ve koruyucu nitelikte olmalıdırlar. Tasarlanan örtü birimi ölçütlere uygun olarak $3 \mathrm{~m}$ hesaplanarak tasarlanmıştır.

\section{Ürün Yapısı}

Öğrenci yer döşemesiyle uyumlu üzerinde estetik bir örtü elemanıyla bütünleşen yaratıcı bir oturma donatısı tasarlamıştır. Kent mobilyasının kentsel açık alanda kullanılması amaçlandığından, örtü ve oturma gibi işlevler bir arada tasarlanmış, böylece mekana uyum sağlanmıştır. Kentsel bir mekân için tasarlanan bu örtü birimi birçok ihtiyaca cevap verecek parçalardan oluşmuştur. Bunlar; bisiklet park yeri, oturma birimleri, yeşil çatı, su olukları ve elektrik enerjisi üretmek için güneş panelleridir.

a) Bisiklet park yeri: Bisiklet park yerleri, bisikletli kullanıcıların da kentsel mekânlarda oturma birimlerini ve oturma birimlerini kullanmalarına fayda sağlar. Güvenli bir şekilde bisikletlerini park edip keyifli vakit geçirmeleri için örtü birimine entegre bisiklet park yeri tasarlanmıştır.

b) Oturma birimleri: Oturma elemanları meydan gibi kamusal alanları yaşayan mekânlara dönüştürürler. İnsanlar; dinlenmek, oturmak, sohbet etmek, izlemek veya gözlem yapmak amacıyla oturma elemanlarını kullanırlar. Bu projede de üst örtü birimi ile uyum sağlayacak bir şekilde estetik ve kullanışlı bir oturma birimi tasarlanmıştır.

c) Yeşil çatı: Her bir yeşil çatı sistemi, yeni bir yaşam alanı anlamına gelmektedir. Yeşil çatı sistemleri ekolojik yapılarda eksik olan unsuru tamamlarken, sürdürülebilir mekânların meydana getirilmesine yardımcı olmaktadır. Bu projede yeşil çatının kullanılması aynı zamanda kentsel konforu ve doğa ile iç içe yaşama arzusunu gidermek amaçlıdır.

d) $\mathrm{Su}$ olukları: $\mathrm{Su}$ olukları üst örtü biriminin yağmurdan topladığı suyu yer altı deposuna ulaştırmak amaçlı kullanılmıştır.

e) Güneş panelleri: Üst örtü biriminin çatısında kullanılan güneş panelleri, kullanıcıların mekânda vakit geçirirken ürünlerini şarj edebilme avantajı sağlamak için kullanılmıştır.

\section{Kentsel Donatı Elemanının Pratik kullanımı}

- Kullanıcıların sorununu karşılayacak asosyalleşme problemine çözüm sunması,

- Kullanıcıların bisiklet park yeri problemine çözüm sunması,

- Doğa ile bütünleşerek vakit geçirme isteğinin karşılanması,

- Kent ekolojisine katkıda bulunmak için yeşil çatı kullanılması,

- Kullanıcıların şarj problemine güneş panellerinden sağlanan enerji ile çözüm sunulması,

- Hareketli oturma birimi sayesinde grup ve bireysel şekilde kullanıcının istediği kombinasyonda oturmasını sağlama özellikleri dikkate alınarak tasarım yapılmıştır.

\subsection{4. Çözümleme-Seçenek Üretme (Eskizler): Senaryomuza Göre Farklı Alternatifler Üretmek}

Tasarım çalışmalarında en önemli aşamalardan biride seçenek üretme aşamasıdır. Burada tasarımcı farklı alternatifler üreterek konuyu farklı açılardan değerlendirir ve en iyi sonuca ulaşmaya çalışır. Öğrencimiz Minel Tantan bu aşamaya kadar elde ettiği bilgiler 1şı̆̆ında oldukça fazla alternatif üretmiştir (Şekil 3). Tasarım konsepti olarak doğal alan eğrileri ve dalgaların çizgisel karakterinden yararlanmıştır. Ayrıca altın oran konsepti kapsamında (Şekil 3'de 2. Seçenek) kademeli bir biçimde oluşan örtü tasarımı çizmiştir. 


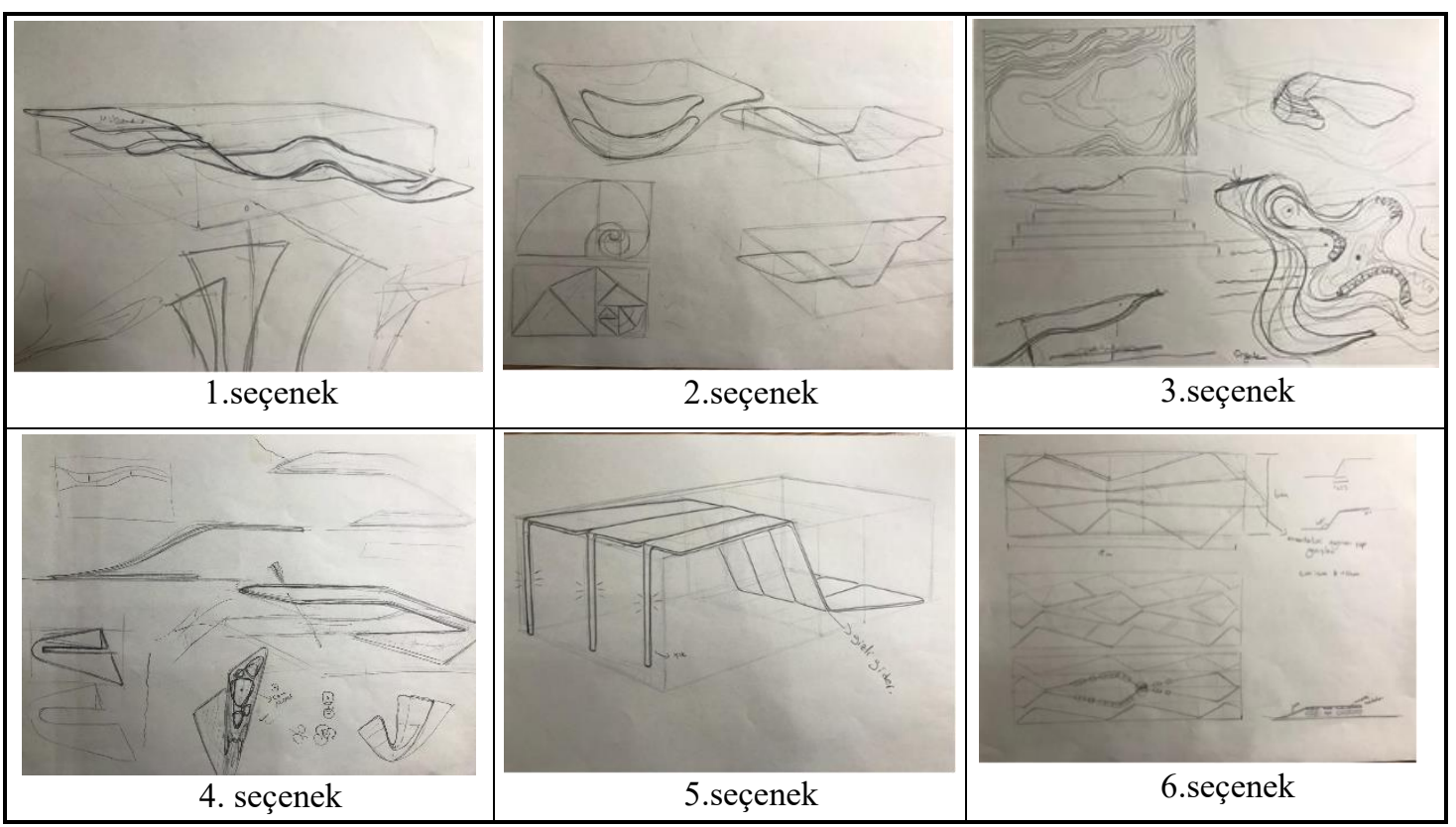

Şekil 3. Seçenek üretme aşaması

\subsubsection{Seçenekler İçinden Seçim Yapma ve Seçilen Donatının Geliştirilmesi}

Bu aşamada üretilen donatı seçeneklerinden en özgün ve işlevsel olanın seçilmesi amaçlanmıştır. Seçilen donatının geliştirilmesi aşamasında artık ürün detayları çözümlenmeye başlanmıştır. Biçimin kesinleşmesi ile ölçüler, malzemeler, renkler, dokular vb. çalışmada yerini alır. Öğrencimiz yeşil dokunun örtünün üstünü tam kaplamasındansa sırt kısmında kalmasını tercih etmiş, örtünün ayak kısmında ise kullanıcıların uzanması, yaslanıp kitap okuması için yeşil dokuyu biçimlendirmiştir (Şekil 4).

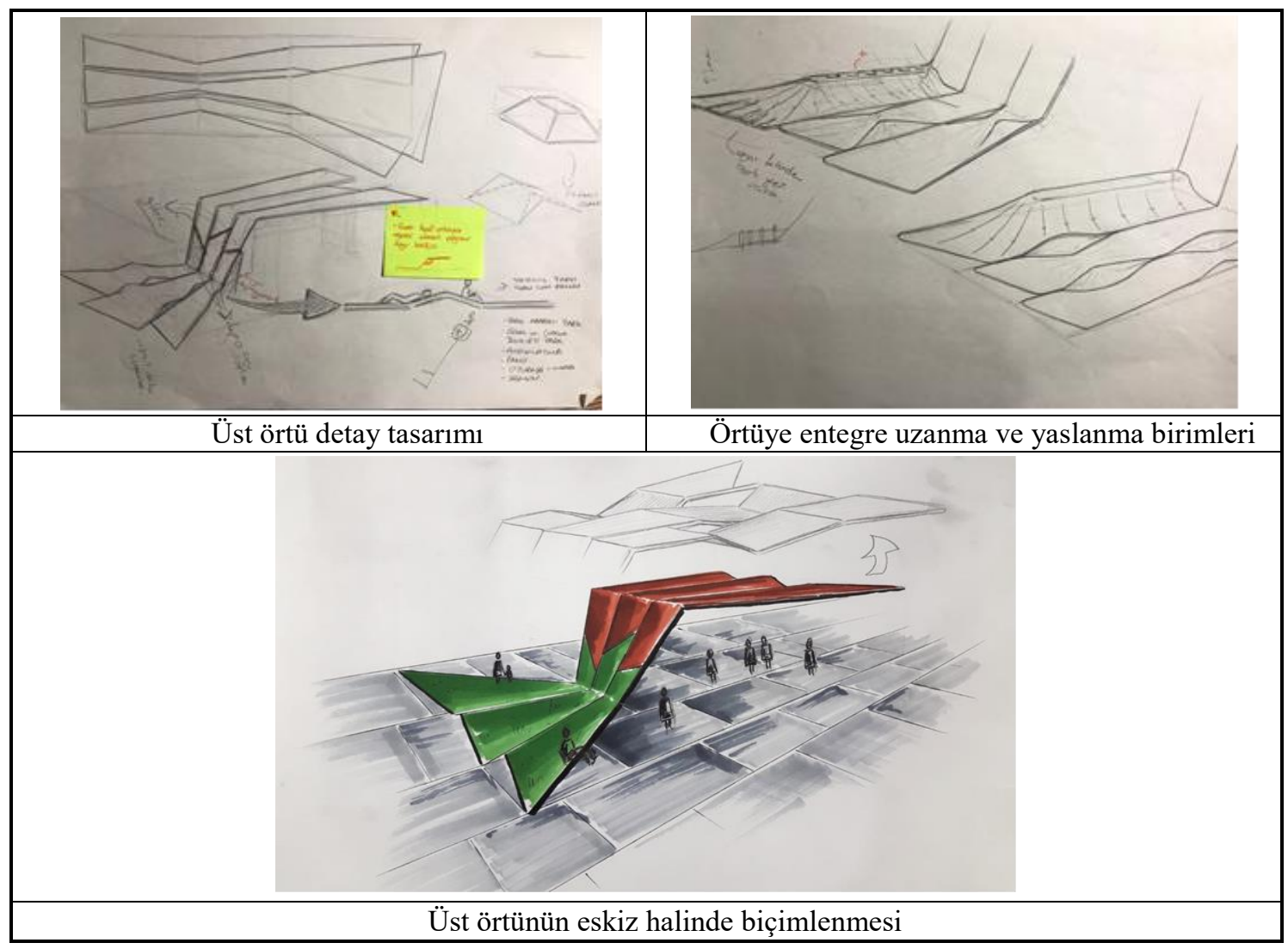

Şekil 4. Seçilen tasarımın geliştirilmesi 


\subsubsection{Sonuç Ürün (3D Modelleme, Maket Ö:1/10)}

En son aşamada çizimlerin tamamlanmasıyla 1/10 ölçeğinde üst örtü ve oturma donatısı tasarımı maket haline dönüştürülmüştür. Bunun yanında bilgisayar ortamında 3D simülasyonlar yapılmıştır. Üst örtünün malzemelerine baktığımızda dış etkilere dayanıklı alüminyum profil taşıyıcı sistem, üst kısım içinde sert plastik kullanılmıştır. Ayrıca 3 parça olan üst örtünün tavan kısımlarında birleşim yerlerinde alta 1şı geçirimini sağlamak için emaye(tamperli) cam malzeme kullanılmıştır. Sabit oturma birimleri için ise yerinde dökme beton üzeri ahşap kaplama olarak karar verilmiştir (Şekil 5).

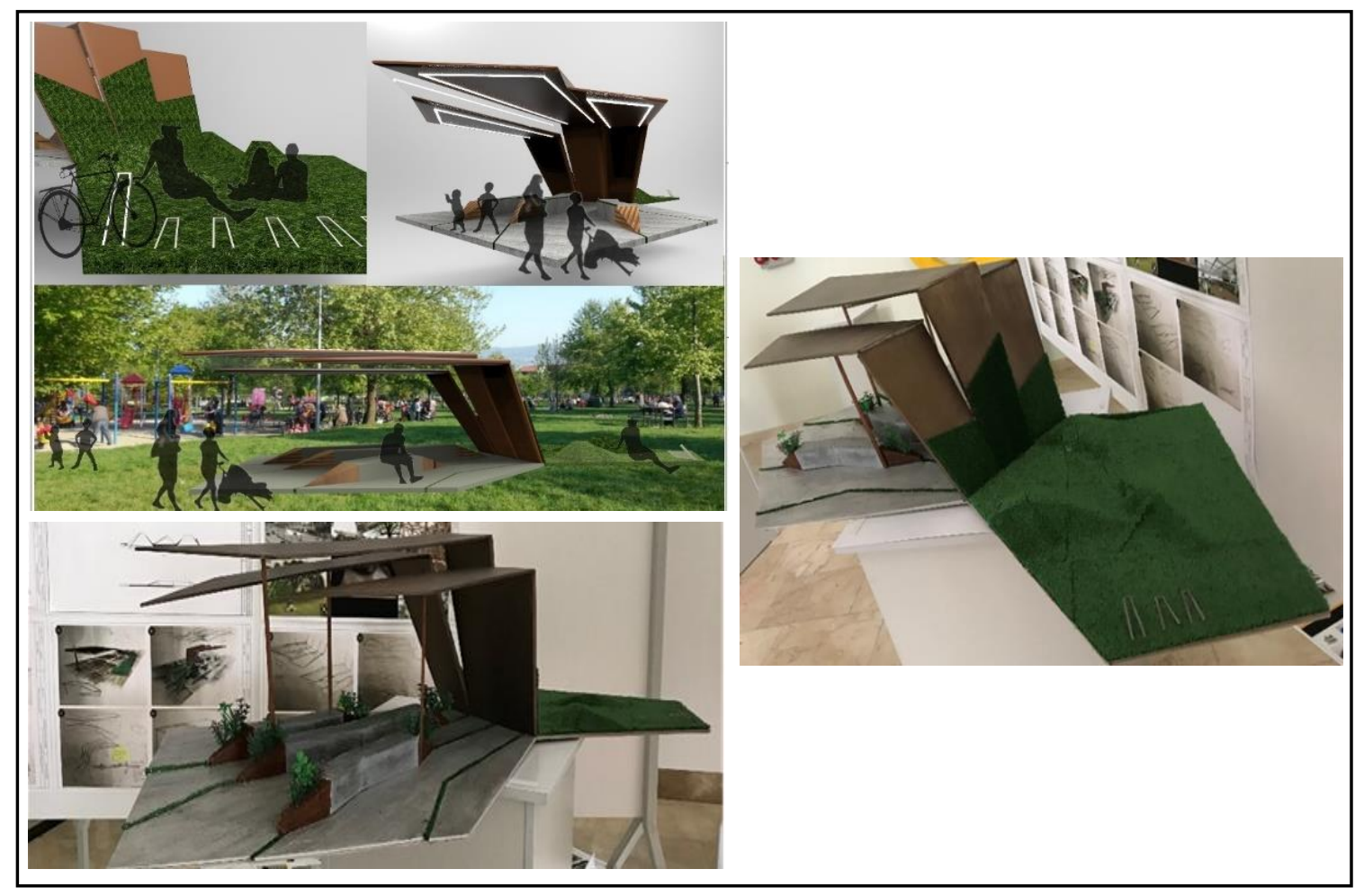

Şekil 5. Sonuç ürün, 3D görseller ve Maket görüntüsü (Minel Tantan tarafından tasarlandı)

\subsection{Piknik Donatısı Tasarımı}

Kentleşme ile birlikte artan yoğun iş yaşamdan uzaklaşmak isteyen insanlar boş vakitlerinde veya çalışmadığı günlerde eğlenceli etkinliklere yönelip stres atmak istemektedirler. Bu stresten uzaklaşmanın ve keyifli vakit geçirmenin yollarından biride piknik yapmaktır. Bu ürün kullanıcılarına daha kolay ve pratik bir kullanım sağlayarak daha keyifli zaman geçirmelerini hedeflemiştir. Piknik yapmak insanların eğlenceli vakit geçirmek, ruhsal ve fiziksel olarak dinlenmek için yaptığı bir etkinliktir. Bu etkinlik insanların vakitlerinin uzun bir bölümünü kapsar. Bu yüzden piknik alanları insanların ihtiyaçlarını karşılayabilecek nitelikte olmalıdır. Bu ürün ile günümüzdeki piknik donatılarının yetersizliğinden yola çıkılarak daha kullanışlı, insan ihtiyaçlarını karşılayan, keyif verici bir tasarım yapılması amaçlanmıştır.

\subsubsection{Kullanıcı İhtiyaçlarının Tanımlanması}

Müşteri ihtiyaçlarını belirlemek için, farklı yaşam alanlarına ait insanlardan ham veriler toplanarak araştırmalara başlanmıştır. Bilecik kenti için (Baş 2003; Yazıcıŏglu, Erdoğan 2004 tablosuna göre ) \pm \%10 örnekleme hatası (d) ile örneklem sayısı 61 olup fazla kişiye ulaşma düşüncesiyle 80 kişiyle yüz yüze görüşülerek anket yapılmıştır. Yapılan anketlerin soru ve cevapları Tablo 3'te detaylıca verilmiştir. 
Tablo 3. Anket Sonuçları

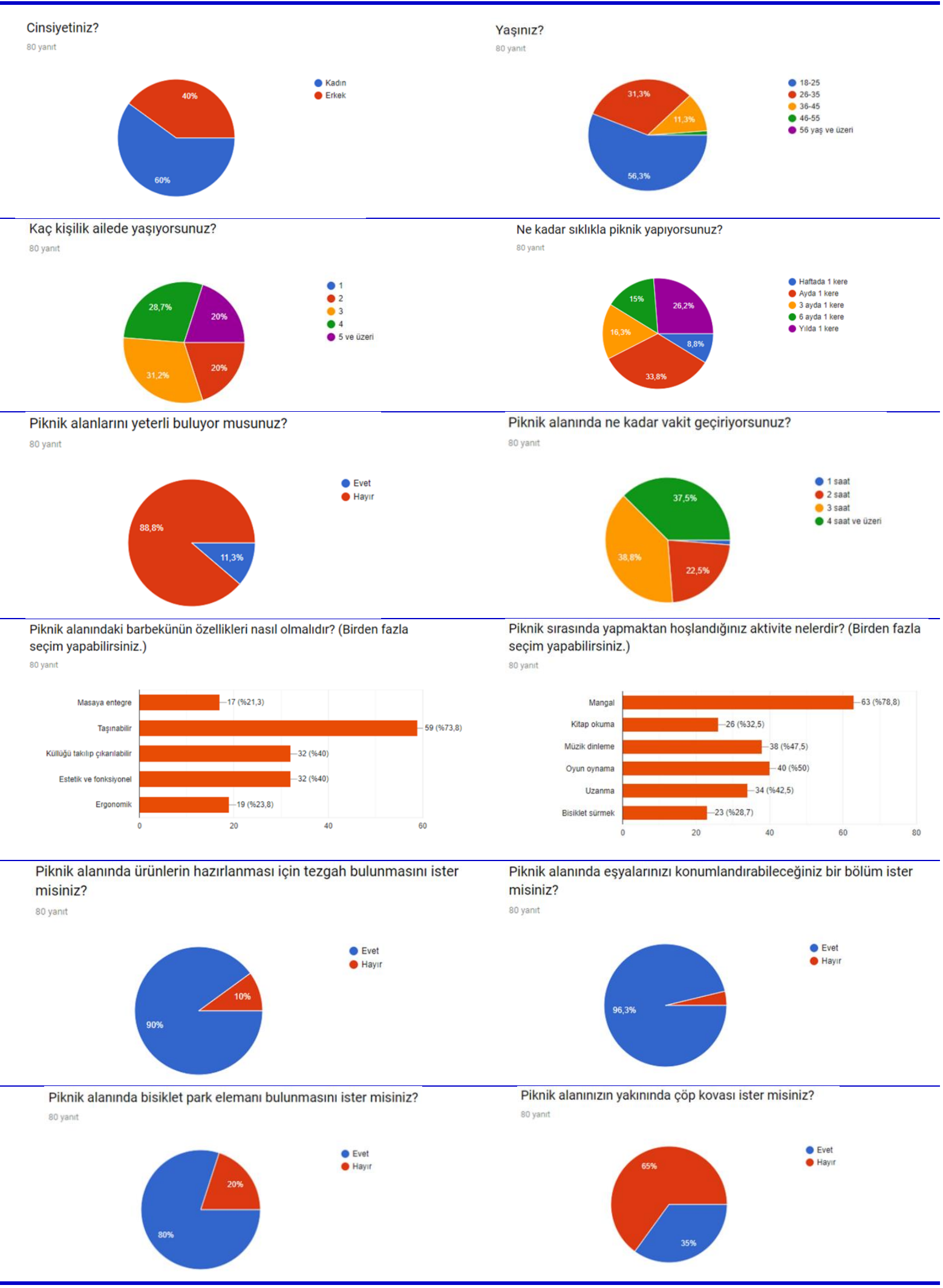




\subsubsection{Kalite Evi}

Kalite evini inşa etmenin ilk adımı olarak tasarım gereksinimleri (müşteri bakış açısıyla belirtir) ile ürün karakteristiği arasındaki ilişkiyi kurmak için müşteri ihtiyaçlarının her biri için bir dizi terim metriği geliştirildi. Bu metriklere genel olarak müşteri ihtiyaçlarını belirledikten sonra ve konsept oluşturulmadan önce kurulan ön spesifikasyonlar denir.

Kent mobilyası kamusal mekanın tasarımındaki işlevi ve temel gereksinimleri karşılamakla beraber, tasarım ve yer seçimi ölçütleri açısından kent kimliğini destekleyecek veya kargaşaya itecek potansiyellere sahiptir. Bu çalışmanın amacı, bireyleri kentsel mekânda, kentsel donatı elemanı ile bir araya getirerek belirli ihtiyaçlarına cevap vererek sosyalleşmelerini sağlamaktır. İlk olarak konu hakkında yapılan literatür araştırması sonucu ihtiyaçları belirlemek için bir anket geliştirilmiştir. Bu anket ile birlikte piyasadaki kentsel donatı birimlerinin ergonomi ve fonksiyonelliği yanında kullanım şekilleri, özellikleri, yapımda kullanılan malzeme ve çeşitleri hakkında saha çalışmaları yapılmıştır.

Tablo 4. Kalite evi

\begin{tabular}{|c|c|c|c|c|c|c|c|c|c|c|c|c|c|c|c|c|}
\hline \multirow{2}{*}{\multicolumn{2}{|c|}{$\begin{array}{c}\text { İhtiyaçlar ve Metrik } \\
\text { İlişkiler }\end{array}$}} & \multicolumn{15}{|c|}{ İHTIYAÇLAR } \\
\hline & & 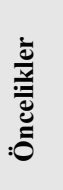 & 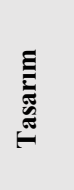 & 晜 & 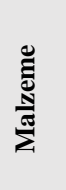 & 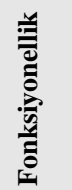 & 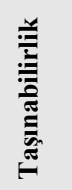 & 气्च & 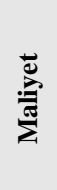 & $\stackrel{\mathscr{E}}{: 0}$ & 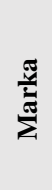 & ư & 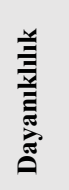 & 䒠 & 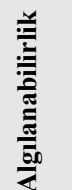 & $\begin{array}{c}\text { TOPLA } \\
\text { M }\end{array}$ \\
\hline \multirow{6}{*}{ 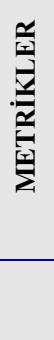 } & Tercih & 1 & 3 & 5 & 4 & 6 & 3 & 5 & 3 & 2 & 1 & 5 & 3 & 1 & & 41 \\
\hline & Kullanım Amacı & 4 & & 3 & & 5 & 8 & & & 4 & & 6 & & & 8 & 34 \\
\hline & İhtiyaç Giderme & 2 & & & 3 & 12 & 8 & & & & & 6 & 4 & & 4 & 37 \\
\hline & Ergonomi & 5 & 8 & & & 6 & 4 & & & 2 & & 4 & 4 & 2 & & 30 \\
\hline & Mekan & 3 & & 5 & 8 & 10 & & 4 & & & & 6 & & 3 & & 36 \\
\hline & TOPLAM & & 11 & 13 & 15 & 39 & 23 & 9 & 3 & 8 & & 27 & 11 & 6 & 12 & \\
\hline
\end{tabular}

\subsubsection{Konsept Oluşturma}

Ürün geliştirmenin temel hedeflerinden biri ürünün ihtiyaçlara cevap verebiliyor olmasıdır. Son kullanıcıya özel ihtiyaçları belirlemek, estetik beklentilerini anlamak, güncel trendleri araştırmak, kullanıcı ortamının başka nelere ihtiyaç duyabileceğini ve ürüne nasıl değer katılabileceğine önem verilir. Müşteri ihtiyaçlarını iyi analiz edebilmek için etkili araştırma yöntemlerini kullanarak çözüm üretilecek problemlerin temel sebepleri tespit edilir. Ürüne ait tanımlamalar yapıldıktan sonra ürüne ait görsel çalışmalar, eskizler, taslaklar çizilmeye başlanır. Alternatif konseptler arasından en makul olanı seçilerek detaylandırılır. Bu süreç tasarımcının daha kontrollü ilerlemesini ve daha somut, anlaşılır bir sonuç elde etmesini sağlar.

\subsection{4. Çözümleme-Seçenekler Üretme}

$\mathrm{Bu}$ aşamada piknik donatısı ve bileşenlerine (barbekü, masa, oturma elemanı vb.) ait seçenekler üretilmiştir (Şekil 6). Öğrencinin yaratıcı ve özgün olması, mobilyanın işlevselliğiyle entegre olarak alternatifler üretilmiştir. Ayrıca yapılan araştırmalarda elde edilen verilerle geri besleme yapılmıştır. Üretilen eskilere bakıldığında kolay servis yapılabilmesi için masanın hareketli olması, oturma biriminin yumuşak hatlı olması, barbekü önünde pişiren kişinin yorulmaması için oturma birimi tasarlanması, maşa tutacağı, eşyalar için raf ve masa üstünde bir bölüm olması gibi işlevlere yer verilmiştir. 


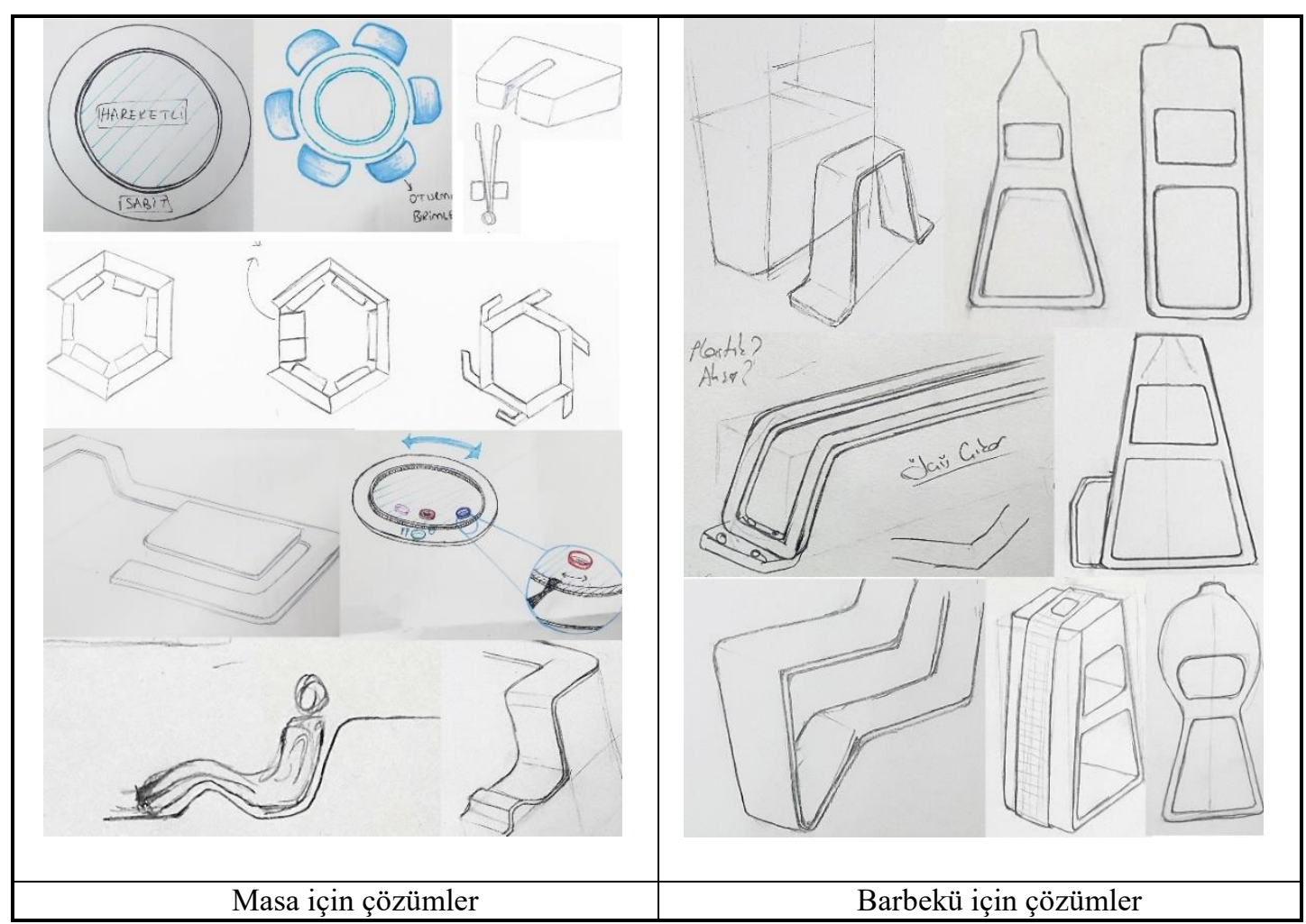

Şekil 6. Eskiz çalışmaları (İzel Durmuş tarafindan tasarlandı)

\subsubsection{Seçenekler İçinden seçim yapma ve Seçilen Ürünü Geliştirme}

Bu aşamada öğrenci tarafından üretilen eskiz seçenekleri arasından çalışma konusuna uygun, özgün nitelikte, estetik ve işlevsel olarak geliştirilebilecek kentsel mobilyaya karar verilerek detay çözümlerine geçilmiştir. Barbekü tasarımında Peri Bacaları doğal oluşumlarından etkilenerek biçimlendirilmiş, devamında sepet ve eşyaları depolama alanı ve yiyeceklerin hazırlanabileceği tezgah oluşturulmuş ve sonrasında bu tezgaha entegre biçimde oturma birimi ortaya çıkmıştır. Masa tasarımda pişirilen yiyeceklerin kolay servis yapılabilmesi veya tekerlekli sandalye kullanan bireylerin kullanılabilmesi için tasarım çizgilerine uygun şekilde masanın bir kısmı iç bükey olarak tasarlanmıştır (Şekil 7.)

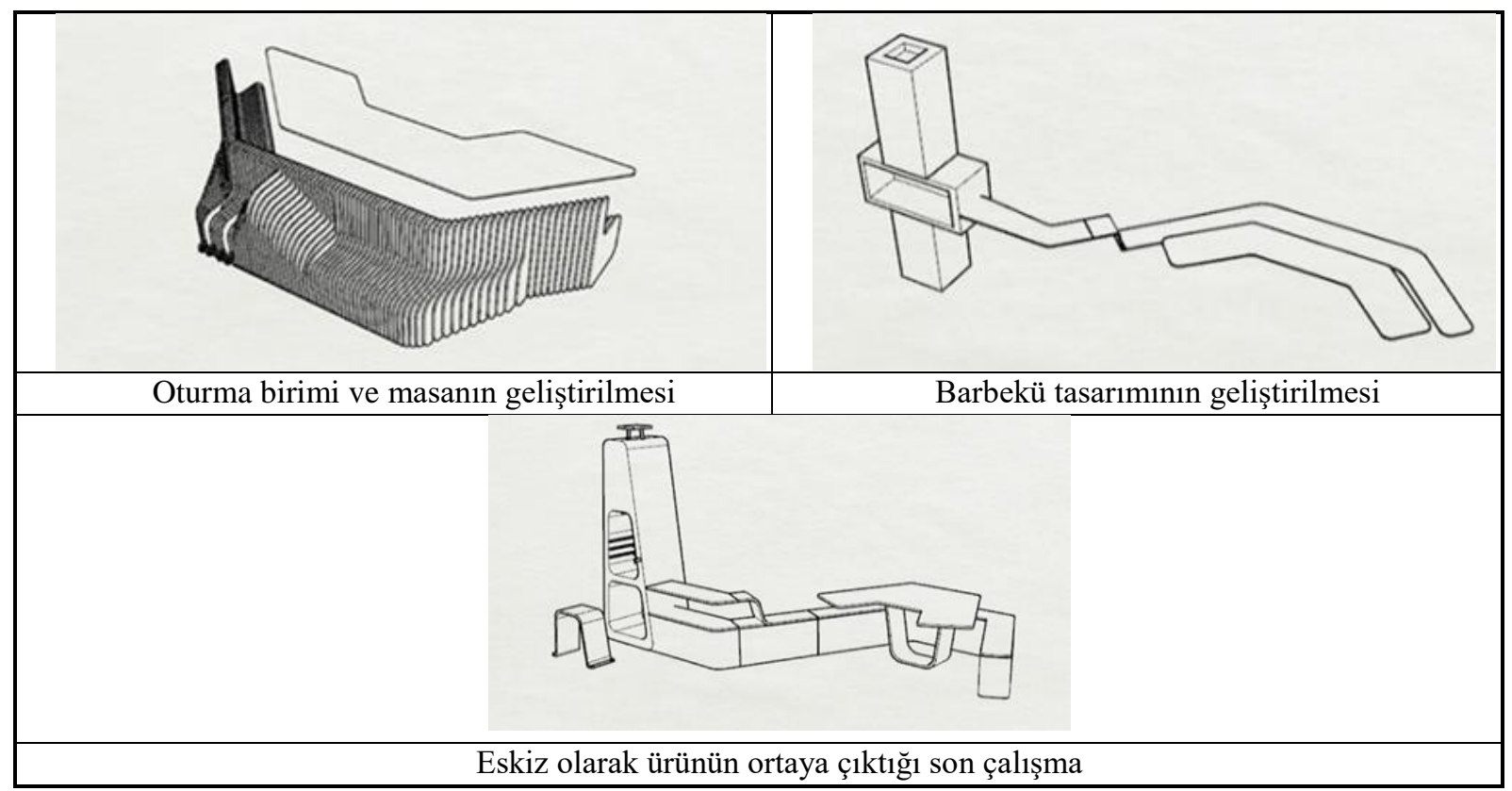

Şekil 7. Seçilen eskiz ürününün geliştirilmesi (İzel Durmuş tarafından tasarlandı) 


\subsubsection{Sonuç Ürün (3D Modelleme, Maket)}

En son aşamada çizimlerin tamamlanmasıyla $1 / 10$ ölçeğinde piknik donatısı tasarımı maket haline dönüştürülmüştür. Bunun yanında bilgisayar ortamında 3D simülasyonlar yapılmıştır. Bu aşamada kent mobilyasının renk, doku gibi estetik özellikleri ve ölçü, form, biçim vb. işlevsel özellikleri algılanabilir hale gelmiştir. Öğrencimiz tasarımında doğal görünümü elde etmek için doğal taş kullanmıştır. Servis tezgahı ve oturma biriminde ise kompakt laminat kullanmıștır. Bunun nedeni kompakt laminat malzemesinin dekoratif olması, su, nem ve çeşitli kimyasallardan etkilenmemesidir.

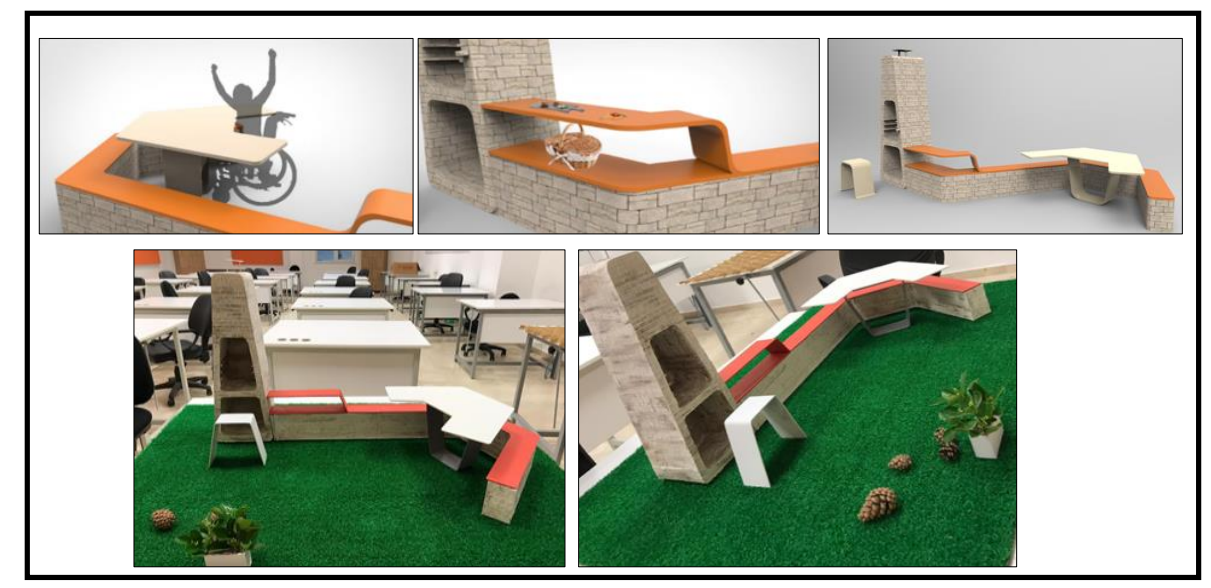

Şekil 8. Sonuç ürün detayları (İzel Durmuş)

\section{Sonuç ve Öneriler}

Kent mobilyaları, kent yaşamını daha zevkli ve anlamlı kılan, kentsel konfor ve kentsel estetik yaratan elemanlar olarak, toplumsal yaşama olumlu katkılarda bulunmaktadırlar. Bu nedenle kentlerin üzerinde yaşayan insanların ihtiyaçlarında ve kültürlerindeki farklılıklar göz önüne alınarak sosyal, kültürel, psikolojik, ekonomik, antropometrik, ergonomik ve demografik açıdan incelenerek düzenlenmelidir (Akyol 2006). Bu özellikler ders kapsamında yapılan çalışmada tasarım aşamalarıyla birlikte ele alınmaya çalışılmıştır.

Sonuç olarak ağırlıklı olarak öğrenciler kentsel mobilyaların uygun ölçü ve biçimde özgün, kullanılabilir ve sürdürülebilir olması konusunda yoğunlaşmışlardır. Bu nedenle öğrenciler kent mobilyası tasarımı sürecinde tasarım yaparken pek çok farklı durumu değerlendirmiştir. Özellikle mobilyanın ölçüleri, biçimi, dokusu yani tüm estetik ve işlevsel kurgularını bir arada değerlendirmişlerdir. Bu yaklaşımla öğrencilerin yaratıcılıkları gelişmiş mekan kimliğine uyumlu mobilya tasarlamışlardır. Kent Mobilyaları Tasarımı ders kapsamında yapılan bu çalışmaların ders öğrenme çıktılarıyla ilişkisini Tablo 5 'te görülmektedir. Tabloya göre öğrenciler tasarladıkları kent mobilyaları ile ders öğrenme çıktılarını kavramışlardır.

Tablo 5. Kentsel donatı elemanlarının ders çıktıları açısından değerlendirilmesi

\begin{tabular}{llll}
\hline Ders Öğrenme Çıtıları & Proje 1 & Proje 2 \\
\hline $\begin{array}{l}\text { 1. Kent donatılarının özelliklerinin kavranması } \\
\text { 2. Kent donatılarının kullanım alanlarını }\end{array}$ & $\checkmark$ & $\checkmark$ \\
$\begin{array}{l}\text { ögrenilmesi } \\
\text { 3. Kent donatılarına ilişkin ergonomik ve }\end{array}$ & $\checkmark$ & $\checkmark$ \\
$\begin{array}{l}\text { fonksiyonel tasarım } \\
\text { olması }\end{array}$ & & \\
\hline $\begin{array}{l}\text { 4. Kent donatılarinin kazanılmış } \\
\text { bilgisinin kazanılması. }\end{array}$ & & \\
\hline
\end{tabular}

Çalışma kapsamında öğrenciler ergonomi ve antropometrik ölçüleri analiz ederek, kullanıcı beklentilerinin ürüne yansıtıldığı, malzeme tercihi ve uygulama kararlarının doğru şekilde belirlendiği bir tasarım süreci sonunda uygulamacıyı ve kullanıcıyı memnun edecek üst örtü birimi, oturma elemanı, barbekü ve piknik masası tasarımını 
gerçekleştirmişlerdir. Ayrıca tasarlanan ögelerin tasarım ilkeleri, estetik, işlevsellik ve çevre ile uyumlu olması da önemli bir husustur.

Bugün hızla gelişen kentleşmenin tahrip edici etkilerini en aza indirgemek ve gündelik yaşamını yapılı çevre baskısı altında sürdürmek zorunda olan insanlara yeşil mekan/alan/cephe/yüzey alternatifleri sunmak amacıyla son zamanlarda üretilen ekolojik ve estetik çözümlerden biri bitkilendirilmiş cephe tasarım ve uygulamalarıdır (İpekçi ve Yüksel 2012). Kentsel tasarımın ayrılmaz bir parçası olan bitkisel materyal üst örtü elemanı tasarımında hem estetik hem de işlevsellik açıdan uygun bir tasarım olduğu görülmektedir.

Tasarlanan piknik donatısı irdelendiğinde; öncelikle tercih edilen malzemenin doğa ile uyumlu olması son derece doğru ve uygun bir materyal olduğu saptanmıştır. Tasarımın tüm detaylarında antropometrik ölçülere dikkat edilerek "herkes için tasarım" niteliğini taşıyan, estetik ve işlevsellik açıdan uygun olduğu belirlenmiştir.

Tasarım disiplinleri eğitim sürecinde 4. sınıf son proje artık bitirme projesidir. Öğrencinin mezun olabilmesi için kendini kanıtlaması gereken bir çalışma yapması beklenir. Bu aşamada öğrenci 3 buçuk yıllık tasarım eğitimi birikimini kullanarak kullanıcılar için ürün tasarımı gerçekleştirir. Bu nedenle yapılan ürün tasarımın somut bir biçimde uygulanabilir olması esastır. Öğrencilerimizin tasarladığ üst örtü ve oturma birimi ve ayrıca barbekü ve piknik donatısı tasarımları uygulanabilir özellikleriyle değerlendirilmelidir. Mezuniyet aşamasındaki öğrencilerle tasarlanan bu kentsel donatılar uygulama projesi olarak yerel yönetimlere sunulabilir ve kamunun kullanımı için üretilebilir.

\section{Kaynaklar}

1. Acar, H., Bekar, M. (2017). Peyzaj mimarlığı eğitiminde bir stüdyo çalışması: Kıyı alanı peyzaj tasarım projesi, MEGARON, c. 12, say1 2, s. 13.

2. Aksu, Ö. V. (2012). Kent Mobilyaları Tasarımında Özgün Yaklaşımlar, İnönü Üniversitesi Sanat Ve Tasarım Dergisi, ISSN: 1309-9876 E-ISSN: 1309-9884, Cilt/ Vol. 2 Sayı/No. 6 (2012): 373-386.

3. Akyol, E. (2006). Kent Mobilyaları Tasarım Ve Kullanım Süreci, İstanbul Teknik Üniversitesi, Fen Bilimleri Enstitüsü, Yüksek Lisans Tezi, İstanbul.

4. Baş, T. (2003). Anket “Anket Nasıl Hazırlanır? Anket Nasıl Uygulanır? Anket Nasıl Değerlendirilir?”, Seçkin Yayıncılık, 222 sayfa Ankara

5. Bayazit, N. (2004). Tasarlama Kuramlarl ve Metotlarl, Birsen Yayınevi, ISBN 975-511-356-8, İstanbul.

6. Bayazit, N. (2012). Endüstri Tasarımı Temel Kavramları, İdeal Kültür Yayıncılık, ISBN 978-605-5729-14-1.

7. Bielefeld, B., EI Khouli, S. (2007). Tasarım Fikirleri, YEM Yayın, 4. Bask1, ISBN: 978-9944-757-36-2.

8. Bulut, Y., Atabeyoğlu, Ö., Yeşil, P. (2008). Erzurum Kent Merkezi Donatı Elemanlarının Ergonomik Özelliklerinin Değerlendirilmesi Üzerine Bir Araştırma, Tarım Bilimleri Dergsi,14 (2) 131-138.

9. Çoban, E., Demir, Z. (2014). Kent Mobilyalarının Bulundukları Mekânlara Etkileri: Düzce Örneği, Düzce Üniversitesi Bilim ve Teknoloji Dergisi, 2, 128-140.

10. Düzenli, T., Mumcu, S., Çiğdem, A. (2018). Peyzaj Mimarlığı Eğitiminde Oturma Donatısı Tasarımı: KTÜ Peyzaj Mimarlığı Bölümü Örneğinde İncelenmesi, Social Sciences (NWSASOS), 13(4):126-134, DOI:10.12739/NWSA.2018.13.4.3C0176.

11. Gamito, M., Sousa, J. (2018). Urban Furniture's Chromatic Planning Methodology: Bucelas, a Case Study. In: Di Bucchianico G., Kercher P. (eds) Advances in Design for Inclusion. AHFE 2017. Advances in Intelligent Systems and Computing, vol 587. Springer, Cham.

12. Gupta, N., Bhatti, V. (2015). Importance of Street Furniture in Urban Landscape. International Journal of latest Trends in Engineering and Technology, Vol:5, Issue 3. ISSN: 2278-621X

13. Güllü, E., Ulcay, Y. (2002). Kalite Fonksiyonu Yayılımı Ve Bir Uygulama, Uludă̆ Üniversitesi MühendislikMimarlık Fakültesi Dergisi, Çilt 7, Sayı 1.

14. Güneroğlu, N., Bekar, M. (2020). Tasarım Sürecinin Bitkisel ve Yapısal Katman Dâhilinde Çözümlenmesi, Bartın Orman Fakültesi Dergisi, 22(1): 9-21.

15. İçemer, S. P. (2015). İç mekan Tasarımında Modüler Seramik Separasyonları. Hacettepe Üniversitesi, Güzel Sanatlar Enstitüsü, Yüksek Lisans Sanat Çalışması Raporu, Ankara.

16. İnceoğlu, M., Aytuğ, A. (2009). Kentsel Mekânda Kalite Kavramı, MEGARON, CíLT VOL. 4 - SAYI NO. 3 , 131-146.

17. İpekçi, C.A., Yüksel, E. (2012). Bitkilendirilmiş Yapı Kabuğu Sistemleri, 6. Ulusal Çatı \& Cephe Sempozyumu, 12 - 13 Nisan, Uludağ Üniversitesi Mühendislik ve Mimarlık Fakültesi - Görükle Kampüsü ,Bursa.

18. Kaya, Ö., Özok, A.F. (2017). Tasarımda Antropometrinin Önemi. Mühendislik Bilimleri ve Tasarım Dergisi, 5 (SI: Ergonomi2016), 209-316. 
19. Rawan, A.H., Morsy, A. A. G. (2016). The Importance of Integratig Street Furniture in the Visual Image of the City, Journal of Modern Engineering Research. Vol: 9, Issue: 2

20. T.C. Milli Eğitim Bakanlığı yayınları (2014). İç Mekanda Tasarım ve Ergonomi.

21. URL-1, (2020). https://acikders.ankara.edu.tr/pluginfile.php/61616/mod_resource/content/1/8. \%20B\%C3 \%B61\%C3\%BCm\%20-\%C3\%87at\%C4\%B1lar.pdf, Halim PERÇíN Ankara Üniversitesi Ziraat Fakültesi Peyzaj Mimarlığı Bölümü Peyzaj Konstrüksiyonu 1 Ders Notları.(10.03.2020)

22. Yazıcıŏ̆lu, Y., Erdoğan, S. (2004). Spss uygulamalı bilimsel araştırma yöntemleri. Detay Yayıncılık, Ankara.

23. Yücel, G.F. (2006). Kamusal Açık Mekanlarda Donatı Elemanlarının Kullanımı. Ege Mimarlık Dergisi, (4) 59.

24. Zavari, S., Utaberta, N., Mydin, M. (2016). Sustainability of Street Furniture Design in Malaysia. Australian Journal of Basic and Applied Science. 10(6) March, 119-121. 